\title{
DEMOGRAPHIC ASPECTS OF TERRITORIAL DISTRIBUTION AND URBANIZATION LEVEL IN THE REPUBLIC OF MACEDONIA
}

\author{
Nikola Panov", Milena Taleska, Hristina Dimeska \\ Institute of Geography, Faculty of Natural Sciences and Mathematics, Ss. Cyril and Methodius University, \\ Skopje, Republic of Macedonia \\ *Corresponding author, e-mail: npanov@pmf.ukim.mk
}

\begin{abstract}
The Republic of Macedonia, like other European countries, is following the trend of continuous decline of the population in some parts of the country. Along with this decline in population, there is also a decline in the rate of population growth and population density occurring in certain regions.On the territory of the Republic of Macedonia, regarding the distribution of population density, visible differences can be observed in some parts, and even regions. These demographic changes happened due to the economical opportunities within the country, and also to the migration movements.In this paper, beside the analysis of the data of the population movement and the density of the population (1953 - 2011), we shall also observe the basic marks of the urban and rural environments, in terms of the changes occurring in spatial distribution by regions as well as identifying the factors that influenced the formation of the disparity in today's asymmetric spatial distribution of the population.
\end{abstract}

Key words: Republic of Macedonia; number of citizens; population growth; urban and rural areas

\section{INTRODUCTION}

Demographic development is a complex process [1] which constitutes natural growth of population (birth rate, fertility, mortality and migration), and changes in demographics structures (biological, socio-economic and educational). There is a strong connection between population movements and its structural marks which is characterized by the influence that these movements have on the structural characteristics and vice versa. On the other hand, there are numerous conditions that influence the changes indirectly and directly, which characterizes the dynamics of the population movement, as well as the demographic structures, considering the biological, socio-economic, ecological, cultural and socio-psychological factors of local, regional and global character. The mentioned factors and the intensity of their influence on the demographics trends are different concerning the dependence upon the situation of the social and economical development of the known territory, in this case, the Republic of Macedonia.
In other words, the population that lives on the territory of the country, from the aspect of demographic development, shows results and regularities, which are typical for economic and social development on the territory [2].

In the last few decades, the Republic of Macedonia has been facing numerous and serious challenges related to demographic development [3] which are consequences of social and economic trends at the moment and their historical dependence.

The analyses of population movement from the aspect of total number, its changes, territorial distribution and urbanization are very important and they show the basic for planning and leading the population policy of regions and countries, planning in agricultures, health, education, social security, special and urban planning and many other spheres of society.

\section{THEORETICAL BACKGROUND AND METHODOLOGY}

Changes and conditions of demographic development can be expressed in a positive or negative way 
in the society [4]. The negative demographical tendencies are present in many parts of the world, and as a result of decreasing birth rates, migration and the ageing population, there is a high risk of demographic desertification, especially in Europe [5].

Demographic processes, such as depopulation has been present on the European continent for a long time [6], and are due to numerous challenges arising from current economic and social conditions, that have a direct impact on demographic trends [7]. These processes are part of a vicious circle of economic and social decline [8]. That is why, over the last several decades, researchers have explored various factors associated with demographic changes, and the scope of the scientific research on this topic worldwide is broad and miscellaneous.

The aim of this paper is to focus on the current situation with the demographic trends in the Republic of Macedonia and to analyze the population movement and population density, to observe the basic characteristics of urban and rural areas in terms of changes occurring in the spatial distribution of the population by regions and to identify the factors that influence today's uneven spatial distribution of population. For example, depopulation is not a recent phenomenon in the Republic of Macedonia and it is evident on the whole territory, however, the awareness of the importance of this phenomenon started to increase rather recently. Thereby, this research can contribute to the analysis and development of links between the demographic projections on the one hand, and socio-economic decision making, on the other hand.

When talking about population and its activities, it is obvious that we deal with complex phenomena [9] which require application of diverse methods that commonly necessitate a great deal of information, as statistical-demographic, geographical, method of comparative analysis, etc. That is why, for the purpose of this study, a combination of secondary and primary data sources research was carried out. The secondary data research aims: firstly, at defining the terms related to the research, and secondly, exposes the different points of view of experts. The primary data research is using the data from the Statistical Office of the Republic of Macedonia. The systemizing and analyzing of the available data from methodological point of view were previously well planned and thought out, which allows scientific approach to the issues. In the article there were used some specific methods, like statistical-demographic, geographical, method of comparative analysis, etc.

\section{RESULTS AND DISCUSSION}

\author{
Total population - The territorial distribution \\ and urbanization
}

\section{Dynamics of change in the number and distribution of the population}

The territory of the Republic of Macedonia covers an area of $25.713 \mathrm{~km}^{2}$, and according to the State Statistical Office, it estimates a population of 2.058.539 inhabitants (2011), or more than 80 inhabitants per $\mathrm{km}^{2}$ [10]. This population density is much lower compared with the European Union, as well as with the most countries in Europe. According to this indicator, Macedonia has ideal conditions for the development of all spheres of life, i.e. its density provides the opportunity for a normal existence and it has the potential to increase the number of population. The analysis of the population movement in the past six decades - totally and locally (at the level of regions and municipalities) shows those changes in population growth, particularly in the spatial distribution of the population in the country, that can be expressed through the continuous deepening of the uneven distribution of population.

In the period before the transition, between 1953-1981, the total population increased by 604.484 people or by $46,3 \%$ (Table 1) [11]. During this period, the largest increase in population was recorded in Skopje region (290.242 people or $135,2 \%$ ), Polog region (94.181 people or 55,7\%) and Southwest region (66.169 people or 47,0 \%). Below average, however, relatively higher population growth is seen in the East $(23,4 \%)$ and Southeast regions $(32,9 \%)$, and with significantly lower growth of the population stand out the Northeast $(17,2 \%)$, the Pelagonian (16,4\%) and Vardar regions (12,8\%). The uneven population growth that occurred before the beginning of the socio-economic transition in the country resulted in major changes in density of population and a large concentration of population in the Skopje region.

The analysis of the data between 1953-1981, indicates, more or less, pronounced differences in the dynamics of the population growth at regional level in between census periods, that were dictated by the different impact of the two components of population growth - the natural increase and the migratory movements of the population. The natural increase of the population contributed to a significant growth and rejuvenation of the population in the Southwest and Polog regions. However, in the Pelagonian region, intense migratory movements 
abroad contributed to the reduction of the population growth and changes in its age structure with far-reaching consequences for the future development of population in this area.

Table 1. The scale and the dynamics of the total population in the Republic of Macedonia, by regions (NUTS 3), 1953-1981

\begin{tabular}{lcccc}
\hline \multicolumn{1}{c}{ Region } & 1953 & 1961 & 1971 & 1981 \\
\hline Republic of Macedonia & 1.304 .652 & 1.428 .526 & 1.647 .308 & 1.909 .136 \\
Vardar & 130.290 & 129.121 & 134.807 & 146.921 \\
East & 139.475 & 144.686 & 157.374 & 172.163 \\
Southwest & 140.678 & 164.770 & 181.323 & 206.827 \\
Southeast & 119.609 & 121.033 & 139.317 & 158.912 \\
Pelagonia & 249.492 & 260.524 & 273.476 & 290.486 \\
Polog & 169.225 & 187.971 & 213.711 & 263.406 \\
Northeast & 141.149 & 148.780 & 158.258 & 165.445 \\
Skopje & 214.734 & 271.641 & 389.042 & 504.976 \\
\hline
\end{tabular}

Source: State Statistical Office, Republic of Macedonia,

SYB, RM/1962; SYB, RM/1972; SYB, RM/1982

The data for some census years in the period between 1953-1981 by municipalities, are showing changes in the population number in some parts of the country (Table 2) [11]. According to the territorial organization in this period, population growth was recorded in all municipalities and in the area of Skopje, except in Berovo, Makedonski Brod, Demir Hisar, Kratovo, Kriva Palanka, Krusevo and Sveti Nikole where the process of depopulation was noticed. These changes at the municipal level has deepened the differences in the spatial distribution of the population at the local level and largely determined the development of the population in the next decades, especially in municipalities where a decrease in the total population was noted.

The data analysis from population censuses in 1994 and 2002 and the estimate population number for 2011 show that in the last two decades very major changes in population growth have occurred in the Republic of Macedonia. In the period 1994-2002, the total population of the country increased by $3,9 \%$ (76.615 people), and the average annual growth rate was $0,48 \%$ (Table 3 ) [12]. At the regional level these indicators show that the Pelagonian region was confronted with depopulation, where the population has decreased by $1,85 \%$ (average annual growth rate is $-0,23$ ). During this period, lowest population growth was seen in the East region $(0,48 \%)$.

In the period 1994-2002, the Polog region differentiates with the highest population growth $8,48 \%$ (23.773 people), with average annual growth rate of $1,02 \%$. In terms of population growth in the Polog region, it is important to emphasize that for five decades, the population has increased from approximately 169.000 (1953) to 304.125 people (2002).

The uneven spatial distribution of the population in the country is confirmed by the indicators for population density and population concentration. In the period 1994-2002, the population density in the country grew from 78 to 81 persons per sq km (Table 4) [13].

In regional terms the increase of the population density corresponds to the total population, or the smallest population density is in the East region, and the largest is in the region of Skopje. In 2002, population density was lowest in the Vardar region (33), and largest in the Skopje region (319 inhabitants per square kilometer). According to the population density, the region of Skopje stands out as one of the most densely populated areas in Europe, and it is almost at the same level as the density of the population in Netherlands, and other most populous regions in Germany, Belgium, etc.

Changes in the density of population in 2011 showed that in the country relatively small increase was noticed. After 2002, the population density was reduced in the regions which were facing the process of depopulation (East and Pelagonian regions), and significant growth was noticed in the Polog and Skopje regions. These regions are differentiated according to the indicators and the concentration of population. In 2011. the Polog, Northeast and Skopje regions accounted more than a half (about $53 \%$ ) of the total population in the country, an enormous concentration in a relatively small space, i.e. $26,2 \%$ of the total territory of the country [10]. 
Table 2. Population growth in municipalities in the Republic of Macedonia, their area and number of settlements, 1953-1981

\begin{tabular}{|c|c|c|c|c|c|c|}
\hline \multirow{2}{*}{ Municipality } & \multirow{2}{*}{$\begin{array}{c}\text { Area in } \\
\mathrm{KM}^{2}\end{array}$} & \multirow{2}{*}{$\begin{array}{l}\text { Number of } \\
\text { settlements }\end{array}$} & \multicolumn{4}{|c|}{ Number of population } \\
\hline & & & 1953 & 1961 & 1971 & 1981 \\
\hline R.Macedonia & 25.713 & 1.750 & 1.304 .514 & 1.406 .003 & 1.647 .308 & 1.909 .136 \\
\hline Berovo & 807 & 16 & 20.438 & 20.043 & 19.949 & 20.227 \\
\hline Bitola & 1.699 & 128 & 102.907 & 111.581 & 124.512 & 137.636 \\
\hline Brod & 924 & 54 & 18.678 & 18.034 & 15.811 & 12.227 \\
\hline Valandovo & 331 & 29 & 11.305 & 8.784 & 9.200 & 11.176 \\
\hline Vinica & 438 & 16 & 15.333 & 14.455 & 16.445 & 18.499 \\
\hline Debar & 264 & 41 & 16.658 & 15.729 & 18.467 & 22.497 \\
\hline Delčevo & 585 & 30 & 21.803 & 18.913 & 21.357 & 23.717 \\
\hline D. Hisar & 431 & 38 & 19.414 & 17.218 & 15.653 & 14.434 \\
\hline Gevgelija & 757 & 34 & 22.254 & 22.988 & 27.284 & 31.814 \\
\hline Gostivar & 1.356 & 90 & 75.080 & 81.734 & 82.501 & 101.028 \\
\hline Kavardarci & 1.134 & 50 & 28.106 & 30.981 & 35.128 & 39.731 \\
\hline Kičevo & 852 & 81 & 41.240 & 39.883 & 44.188 & 51.422 \\
\hline Kočani & 571 & 46 & 33.494 & 38.136 & 43.820 & 47.922 \\
\hline Kratovo & 376 & 31 & 16.180 & 15.912 & 15.084 & 12.392 \\
\hline K. Palanka & 720 & 52 & 33.844 & 31.536 & 29.833 & 26.935 \\
\hline Kruševo & 201 & 24 & 13.514 & 13.367 & 13.015 & 13.286 \\
\hline Kumanovo & 1.190 & 109 & 89.977 & 99.920 & 113.341 & 126.118 \\
\hline Negotino & 736 & 34 & 17.381 & 15.682 & 17.784 & 21.131 \\
\hline Ohrid & 1.031 & 57 & 43.565 & 47.295 & 54.019 & 64.230 \\
\hline Prilep & 1.824 & 107 & 87.609 & 93.216 & 96.446 & 99.770 \\
\hline Probištip & 326 & 37 & 14.557 & 15.283 & 15.128 & 15.188 \\
\hline Radoviš & 736 & 50 & 25.887 & 22.358 & 25.925 & 28.575 \\
\hline Resen & 739 & 44 & 24.400 & 23.730 & 23.840 & 25.360 \\
\hline Struga & 541 & 52 & 38.067 & 42.417 & 48.838 & 56.451 \\
\hline Strumica & 953 & 74 & 59.015 & 65.491 & 76.908 & 87.347 \\
\hline S. Nikole & 645 & 45 & 25.272 & 23.169 & 21.142 & 21.260 \\
\hline Tetovo & 1.081 & 93 & 92.997 & 104.825 & 131.210 & 162.378 \\
\hline Veles & 1.536 & 90 & 58.241 & 57.877 & 60.753 & 64.799 \\
\hline Štip & 810 & 73 & 32.702 & 36.444 & 40.675 & 46.610 \\
\hline Gazi Baba & 489 & 39 & - & - & - & 92.472 \\
\hline Karpoš & 319 & 23 & - & - & - & 121.746 \\
\hline K. Voda & 729 & 48 & - & - & - & 114.176 \\
\hline Center & 8 & 1 & - & - & - & 93.614 \\
\hline Cair & 282 & 15 & - & - & - & 82.924 \\
\hline Skopje & 1.840 & 126 & 213.586 & 270.299 & 388.962 & 504.932 \\
\hline
\end{tabular}

Source: State Statistical Office of the Republic of Macedonia, SYB RM/1962, SYB PM/1972, SYB PM/1982 
Chart 1. Population growth in the Republic of Macedonia, 1953-2011

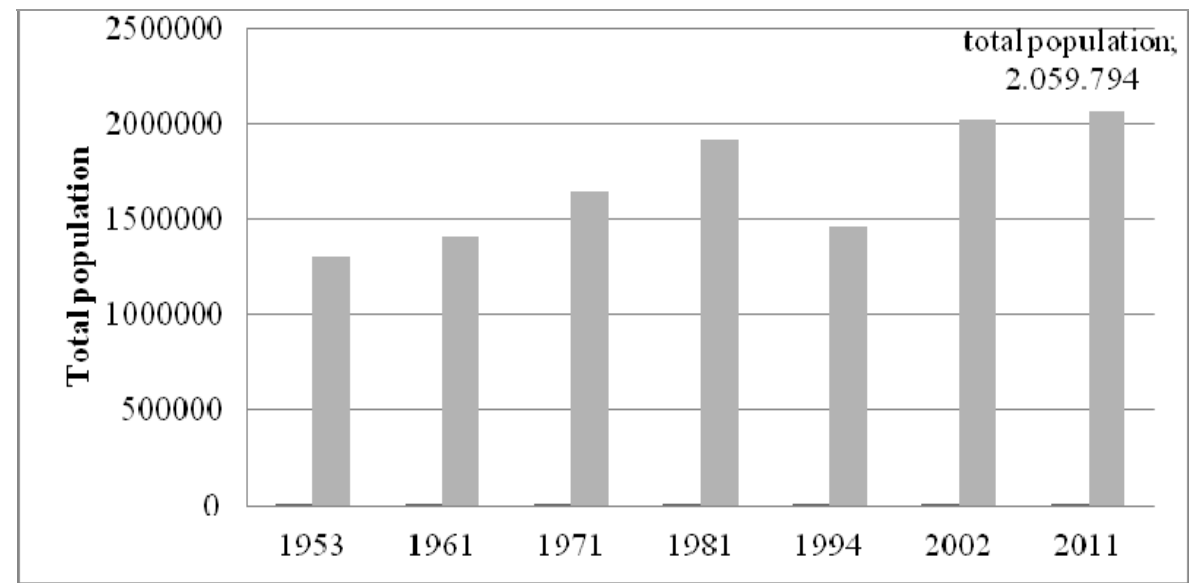

Table 3. Some indications of the scale and dynamics of the total population in the Republic of Macedonia, by regions (NUTS 3) 1994, 2002, 2011

\begin{tabular}{lcccccc}
\hline \multirow{2}{*}{ Region } & \multicolumn{3}{c}{ Total population } & \multicolumn{2}{c}{$\begin{array}{c}\text { Population growth } \\
(1994-2002)\end{array}$} & $\begin{array}{c}\text { Rate of population } \\
\text { growth 1994-2002 }\end{array}$ \\
\cline { 2 - 5 } & 1994 & 2002 & 2011 & Number & $\%$ & \\
\hline R. Macedonia & 1.945 .932 & 2.022 .547 & 2.059 .794 & 76.615 & 3,94 & 0,48 \\
Vardar & 131.035 & 133.180 & 153.764 & 2.145 & 1,64 & 0,2 \\
East & 201.525 & 203.213 & 179.083 & 1.688 & 0,84 & 0,1 \\
Southwest & 212.856 & 221.546 & 221.219 & 8.690 & 4,08 & 0,49 \\
South East & 168.481 & 171.416 & 173.083 & 2.935 & 1,74 & 0,22 \\
Pelagonia & 242.614 & 238.136 & 233.306 & -4.478 & $-1,85$ & $-0,23$ \\
Polog & 280.352 & 304.125 & 316.517 & 23.773 & 8,48 & 1,02 \\
Northeast & 163.841 & 172.787 & 175.323 & 8.946 & 5,46 & 0,66 \\
Skopje & 545.228 & 578.144 & 607.502 & 32.916 & 6,04 & 0,73 \\
\hline
\end{tabular}

Source: State Statistical Office, R. Macedonia, calculations are based on the data from the SSO, Demographic Statistics by regions and Census of population, households and dwellings in the Republic of Macedonia, 2002 (Book XIII)

Table 4. Population density and concentration of population in the country and at regional level, (NUTS 3), 1994, 2002 and 2011

\begin{tabular}{|c|c|c|c|c|c|c|c|c|c|}
\hline \multirow[t]{2}{*}{ Region } & \multicolumn{3}{|c|}{ Total population } & \multicolumn{3}{|c|}{ Population density } & \multicolumn{3}{|c|}{$\begin{array}{c}\text { Concentration of population } \\
(\mathrm{RM}=100.0)\end{array}$} \\
\hline & 1994 & 2002 & 2011 & 1994 & 2002 & 2011 & 1994 & 2002 & 2011 \\
\hline R. Macedonia & 1.945 .932 & 2.022 .547 & 2.059 .794 & 78,1 & 81,2 & 82,7 & 100,0 & 100,0 & 100,0 \\
\hline Vardar & 131.035 & 133.180 & 153.764 & 32,4 & 32,9 & 38,0 & 6,7 & 6,6 & 7,5 \\
\hline East & 201.525 & 133.180 & 179.080 & 57,0 & 57,5 & 50,6 & 10,4 & 10,0 & 8,7 \\
\hline Southwest & 212.856 & 203.213 & 221.219 & 63,7 & 66,3 & 66,2 & 10,9 & 11,0 & 10,7 \\
\hline Southeast & 168.481 & 171.416 & 173.083 & 61,5 & 62,6 & 63,2 & 8,7 & 8,5 & 8,4 \\
\hline Pelagonia & 242.614 & 238.136 & 233.306 & 51,4 & 50,5 & 49,5 & 12,5 & 11,8 & 11,3 \\
\hline Polog & 280.352 & 304.125 & 316.517 & 116,1 & 125,9 & 131,0 & 14,4 & 15,0 & 15,4 \\
\hline Northeast & 163.841 & 172.787 & 175.323 & 70,9 & 74,8 & 75,9 & 8,4 & 8,5 & 8,5 \\
\hline Skopje & 545.228 & 578.144 & 607.502 & 300,7 & 319,1 & 335,3 & 28,0 & 28,6 & 29,5 \\
\hline
\end{tabular}

Source: calculations are based on data from the State Statistical Office; Demographic Statistics by regions and Census of population, households and dwellings in the Republic of Macedonia, 2002 (Book XII)

Differences in the growth of the population are still more pronounced on the municipality level.
In the period 1994-2002 from 67 municipalities (excluding those from the Skopje region - in 
absence of population data for all 17 municipalities in the Skopje region in 1994, and according to the territorial organization from 2004, the population growth in certain municipalities cannot be recorded) population reduction was observed in 35 , while population growth in 32 municipalities (Table 5) [12]. In 2002, 35 municipalities accounted for $42 \%$, and in 2011, 45 municipalities accounted more than a half $(53 \%)$ of the total population of the country. Prominent differences were observed in the Arachinovo municipality, where 362 inhabitants live on $1 \mathrm{~km}^{2}\left(1 \mathrm{~km}^{2} / 362 \mathrm{i}\right)$. On the contrary, in Makedonski Brod on $1 \mathrm{~km}^{2}$ there is an incredible number of just 8,3 inhabitants, that is less than in some Saharan regions, in Rankovce their number is 17.3, and in Kriva Palanka 41 inhabitans.

\section{Urban population and urbanization level}

Major changes in the distribution and redistribution of the population, have considerably increased the heterogeneity in its internal distribution and have emphasized its spatial demographic polarization. It is expressed with high concentrations in the urban areas and with major reductions in the rural areas.

Table 5. The scale and the dynamics of the total population in the country, at regional level (NUTS 3 ) and municipalities (NUTS 5), 1994, 2002 and 2011

\begin{tabular}{|c|c|c|c|c|c|c|c|c|}
\hline \multirow{2}{*}{$\begin{array}{l}\text { Region } \\
\text { Municipality }\end{array}$} & \multirow{2}{*}{$\begin{array}{c}\text { Area in } \\
\mathrm{km}^{2}\end{array}$} & \multirow{2}{*}{$\begin{array}{l}\text { Number of } \\
\text { settlements }\end{array}$} & \multicolumn{3}{|c|}{ Total population } & \multicolumn{3}{|c|}{ Population density } \\
\hline & & & 1994 & 2002 & 2011 & 1994 & 2002 & 2011 \\
\hline R. Macedonia & 25.713 & & 1.945 .932 & 2.022.547 & & 78,1 & 81,2 & \\
\hline Vardar & 3.263 & 170 & 131.035 & 133.180 & 133.125 & 38,6 & 39,3 & 40,8 \\
\hline Veles & 421 & 29 & 54.663 & 55.108 & 55.057 & 128 & 129,1 & 130,8 \\
\hline Gradsko & 293 & 15 & 3.822 & 3.760 & 3.613 & 16,3 & 16 & 12,3 \\
\hline Časka & 829 & 42 & 7.457 & 7.673 & 7.761 & 9,1 & 9,4 & 9,4 \\
\hline Kavadarci & 935 & 40 & 37.699 & 38.741 & 39.011 & 38 & 39,1 & 41,7 \\
\hline Rosoman & 132 & 10 & 4.238 & 4.141 & 4.129 & 32,1 & 31,4 & 31,3 \\
\hline Demir Kapija & 301 & 15 & 4.815 & 4.545 & 4.135 & 15,6 & 14,7 & 13,7 \\
\hline Negotino & 352 & 19 & 18.341 & $19 . .212$ & 19.419 & 38,4 & 40,2 & 55,2 \\
\hline East & 4.162 & 263 & 201.525 & 203.213 & 199.682 & 48,1 & 48,5 & 48 \\
\hline Berovo & 598 & 10 & 14.179 & 13.941 & 13.337 & 23,7 & 23,3 & 22,3 \\
\hline Pehčevo & 206 & 7 & 5.650 & 5.517 & 5.140 & 27,2 & 26,5 & 25 \\
\hline Vinica & 432 & 16 & 19.063 & 19.938 & 19.542 & 44 & 46 & 45,2 \\
\hline Delčevo & 432 & 22 & 17.726 & 17.505 & 16.848 & 42 & 41,5 & 39 \\
\hline M. Kamenica & 179 & 9 & 8.084 & 8.110 & 7.810 & 42,5 & 42,7 & 43,6 \\
\hline Zrnovci & 51 & 3 & 3.344 & 3.264 & 3.134 & 59,7 & 58,3 & 61,5 \\
\hline Kočani & 362 & 28 & 36.775 & 38.092 & 38.155 & 102,2 & 105,8 & 105,4 \\
\hline Česinovo & 134 & 14 & 7.896 & 7.490 & 7.172 & 59,8 & 56,7 & 53,5 \\
\hline Probištip & 326 & 37 & 16.650 & 16.193 & 15.188 & 51,1 & 49,7 & 46,6 \\
\hline Lozovo & 175 & 11 & 2.916 & 2.858 & 2.637 & 17,6 & 17,2 & 15,1 \\
\hline S. Nikole & 477 & 33 & 18.528 & 18.497 & 18.060 & 38,4 & 38,3 & 37,9 \\
\hline Karbinci & 239 & 29 & 4.342 & 4.012 & 4.061 & 19 & 17,5 & 17 \\
\hline Štip & 551 & 44 & 46.372 & 47.796 & 48.598 & 79,5 & 82 & 88,2 \\
\hline Southwest & & & 212.823 & 221.546 & & 63,7 & 66,3 & \\
\hline Debar & 145 & 18 & 18.978 & 19.542 & 20.329 & 126,5 & 130,3 & \\
\hline Centar Župa & 123 & 23 & 6441 & 6.519 & 6.921 & 62,5 & 63,3 & \\
\hline Vraneštica & 122 & 15 & 1.650 & 1.322 & 1.258 & 15,1 & 12,1 & \\
\hline Drugovo & 369 & 28 & 3.555 & 3.249 & 2.987 & 9,3 & 8,5 & \\
\hline Zajas & 155 & 13 & 10.055 & 11.605 & 11.867 & 62,5 & 72,1 & \\
\hline Kičevo & 49 & 7 & 27.543 & 30.138 & 30.269 & 562,1 & 615,1 & \\
\hline Oslomej & & & 9.136 & 10.420 & & 75,5 & 86,1 & \\
\hline M. Brod & 851 & 51 & 7.574 & 7.141 & 6.552 & 8,5 & 8 & \\
\hline Plasnica & 54 & 4 & 4.449 & 4.545 & 4.774 & 82,4 & 84,2 & \\
\hline Debarca & 414 & 30 & 6.272 & 5.507 & 4.555 & 14,9 & 13 & \\
\hline Ohrid & 378 & 29 & 54.491 & 55.749 & 54.269 & 138,7 & 141,9 & \\
\hline Vevčani & 35 & 1 & 2.448 & 2.433 & 2.433 & 106,4 & 105,8 & \\
\hline Struga & 468 & 51 & 60.231 & 63.376 & 64.657 & 124,7 & 131,2 & \\
\hline
\end{tabular}


Table 5 Continues

\begin{tabular}{|c|c|c|c|c|c|c|c|c|}
\hline Southeast & 2.803 & 190 & 168.481 & 171.416 & 173.056 & 61,5 & 62,6 & 61,7 \\
\hline Valandovo & 331 & 30 & 12.092 & 11.890 & 11.944 & 36,5 & 35,9 & 36,1 \\
\hline Bogdanci & 114 & 4 & 8.899 & 8.707 & 8.443 & 77,4 & 75,7 & 74,1 \\
\hline Gevgelija & 532 & 17 & 22.267 & 22.988 & 22.934 & 46,1 & 47,6 & 43,1 \\
\hline Dojran & 127 & 13 & 3.651 & 3.426 & 3.338 & 28,3 & 26,6 & 26,3 \\
\hline Konče & 323 & 15 & 3.713 & 3.536 & 3.576 & 15,9 & 15,2 & 11,1 \\
\hline Radoviš & 487 & 36 & 26.812 & 28.244 & 28.748 & 53,9 & 56,8 & 59 \\
\hline Bosilovo & 149 & 16 & 14.348 & 14.260 & 14.114 & 88,6 & 88 & 94,7 \\
\hline Vasilevo & 171 & 18 & 11.409 & 12.122 & 12.641 & 49,6 & 52,7 & 73,9 \\
\hline Novo Selo & 231 & 16 & 11.954 & 11.567 & 11.038 & 50,2 & 48,6 & 47,8 \\
\hline Strumica & 338 & 25 & 53.336 & 54.676 & 56.280 & 166,2 & 170,3 & 166,5 \\
\hline Pelagonija & 4.688 & 343 & 242.614 & 238.136 & 233.628 & 51,4 & $\mathbf{5 0 , 5}$ & 49,8 \\
\hline Bitola & 771 & 67 & 96.607 & 95.385 & 93.380 & 122,8 & 121,2 & 121,1 \\
\hline Mogila & 251 & 23 & 7.333 & 6.710 & 6.504 & 28,8 & 26,3 & 25,9 \\
\hline Novaci & 754 & 41 & 4.263 & 3.549 & 3.350 & 5,7 & 4,7 & 4,4 \\
\hline D. Hisar & 492 & 41 & 10.610 & 9.497 & 8.734 & 22,1 & 19,8 & 17,8 \\
\hline Kruševo & 183 & 19 & 9.821 & 9.684 & 9.585 & 51,4 & 50,7 & 52,4 \\
\hline Dolneni & 404 & 37 & 13.669 & 13.568 & 13.817 & 33,2 & 32,9 & 34,2 \\
\hline Krivogaštani & 86 & 12 & 6.464 & 6.150 & 5.805 & 72,6 & 69,1 & 67,5 \\
\hline Prilep & 1.170 & 59 & 76.166 & 76.768 & 76.236 & 63,5 & 64 & 65,2 \\
\hline Resen & 577 & 44 & 17.681 & 16.825 & 16.217 & 32,1 & 30,5 & 28,1 \\
\hline Polog & 2.327 & 184 & 280.385 & 304.125 & 315.964 & 116,1 & 125,9 & 135,8 \\
\hline Vrapčište & 185 & 15 & 23.408 & 25.399 & 26.963 & 148,2 & 160,8 & 145,7 \\
\hline Gostivar & 409 & 35 & 74.730 & 81.042 & 82.725 & 145,7 & 158 & 202,3 \\
\hline Mavrovo I R. & 655 & 42 & 10.076 & 8.618 & 8.874 & 15,2 & 13 & 13,5 \\
\hline Bogovinje & 140 & 14 & 25.137 & 28.997 & 30.257 & 177 & 204,2 & 216,1 \\
\hline Brvenica & 163 & 10 & 14.793 & 15.855 & 16.454 & 90,2 & 96,7 & 100,9 \\
\hline Želino & 200 & 18 & 21.760 & 24.390 & 26.915 & 108,3 & 121,3 & 134,6 \\
\hline Jegunovce & 174 & 17 & 10.283 & 10.790 & 10.869 & 58,1 & 61 & 62,5 \\
\hline Tearce & 136 & 13 & 20.797 & 22.454 & 22.767 & 152,9 & 165,1 & 167,4 \\
\hline Tetovo & 265 & 20 & 79.401 & 86.580 & 90.140 & 303,1 & 330,5 & 340,2 \\
\hline Southeast & 2.336 & 192 & 163.841 & 172.787 & 175.709 & 70,9 & 74,8 & 75,2 \\
\hline Kratovo & 376 & 31 & 10.898 & 10.441 & 9.784 & 29,1 & 27,8 & 26 \\
\hline K. Palanka & 488 & 34 & 20.782 & 20.820 & 20.820 & 43,3 & 43,4 & 42,7 \\
\hline Rankovce & 239 & 18 & 4.347 & 4.144 & 3.871 & 18 & 17,2 & 16,2 \\
\hline Kumanovo & 526 & 48 & 97.487 & 105.484 & 107.632 & 191,5 & 207,2 & 204,6 \\
\hline Lipkovo & 269 & 22 & 24.351 & 27.058 & 29.298 & 89,2 & 99,1 & 108,9 \\
\hline S. Nagoričane & 438 & 39 & 5.976 & 4.840 & 4.304 & 13,8 & 11,2 & 9,8 \\
\hline Skopje & & & 545.228 & 578.144 & & 300,7 & 318,9 & \\
\hline Gazi Baba & 112 & 14 & & 72.617 & 75.893 & & 648,4 & \\
\hline Aračinovo & 40 & 3 & & 11.597 & 12.838 & & 374,1 & \\
\hline Ilinden & 92 & 12 & & 15.894 & 16.607 & & 163,9 & \\
\hline Petrovec & & & & 8.255 & & & 40,9 & \\
\hline Gorče Petrov & & & & 41.634 & & & 621,4 & \\
\hline Karpoš & 105 & 3 & & 59.666 & 60.363 & & $1.704,7$ & \\
\hline Saraj & & & & 35.408 & & & 154,6 & \\
\hline Aerodrom & 21 & 1 & & 72.009 & & & 3429 & \\
\hline Zelenikovo & 176 & 14 & & 4.077 & 4.587 & & 23 & \\
\hline Kisela Voda & & & & 57.236 & & & $1.683,4$ & \\
\hline Sopište & & & & 5.656 & & & 25,5 & \\
\hline Studeničani & & & & 17.246 & & & 62,5 & \\
\hline Centar & 8 & 1 & & 45.412 & & & $5.676,5$ & \\
\hline Butel & 55 & 6 & & 36.154 & & & 657,3 & \\
\hline Čair & & & & 64.773 & & & $16.193,3$ & \\
\hline Šuto Orizari & 6 & 2 & & 22.017 & & & $3.145,3$ & \\
\hline Čučer Sandevo & & & & 8.493 & & & 36,0 & \\
\hline
\end{tabular}

Source: State Statistical Office, Census of Population, Households and Dwellings in the Republic of Macedonia, (Book XIII), population estimates, www.stat.gov.mk 
In the second half of the $20^{\text {th }}$ century, under the influence of the intense internal migratory movements (from village to town), in the Republic of Macedonia rather large increase in the share of the total urban population was recorded, that in 2002 reached $56,7 \%$. The share of urban population in the total level of regions ranges from 29,2\% (Polog) to 71,8 \% (Skopje region). By higher values of this indicator there are also distinguished the Vardar, Pelagonia and East regions. Low representation of urban population is characteristic of Southwest and Southeast (Table 6) [13].

Physical and demographic polarization reflected on the changes in the redistribution of popu- lation in urban settlements by size. In 2002 Macedonia had 22 small towns (20.000 inhabitants), 7 medium (20.000-50.000) and 4 major cities (between 50.001 and 100.000). Skopje was the only urban settlement with over 100.000 residents. In terms of spatial distribution of the urban population an interesting fact is its concentration in cities according to their size. Thus, the share of the population of small towns in the total urban population accounted for $17,2 \%, 22,8 \%$ in medium and large cities in $23,8 \%$ in large cities In $2002,36,2 \%$ of the urban population lived in Skopje.

Table 6. Number and participation (in \%) of urban and rural population in Republic of Macedonia, and by regions (NUTS 3) 1994-2002

\begin{tabular}{|c|c|c|c|c|c|c|}
\hline & \multicolumn{3}{|c|}{ Census 1994} & \multicolumn{3}{|c|}{ Census 2002} \\
\hline & Total & Urban & Other & Total & Urban & Other \\
\hline \multicolumn{7}{|c|}{ R. Macedonia } \\
\hline Number & 1.945 .932 & & & 2.022 .547 & 1.147 .006 & 875.541 \\
\hline$\%$ & 100 & & & 100 & 56,7 & 43,3 \\
\hline \multicolumn{7}{|l|}{ Vardar } \\
\hline Number & 152.479 & 104.143 & 48.336 & 154.535 & 106.207 & 48.328 \\
\hline$\%$ & 100 & 68,3 & 31,7 & 100 & 68,7 & 31,3 \\
\hline \multicolumn{7}{|l|}{ East } \\
\hline Number & 180.081 & 111.345 & 68.736 & 181.858 & 120.547 & 61.311 \\
\hline$\%$ & 100 & 61,8 & 38,2 & 100 & 66,3 & 33,7 \\
\hline \multicolumn{7}{|c|}{ Southwest } \\
\hline Number & 212.856 & 99.010 & 113.846 & 221.546 & 79.964 & 141.582 \\
\hline$\%$ & 100 & 46,5 & 53,5 & 100 & 36,1 & 63,9 \\
\hline \multicolumn{7}{|c|}{ Southeast } \\
\hline Number & 168.481 & 74.497 & 93.984 & 171.416 & 77.632 & 93.784 \\
\hline$\%$ & 100 & 44,2 & 55,8 & 100 & 45,3 & 54,7 \\
\hline \multicolumn{7}{|c|}{ Pelagonia } \\
\hline Number & 242.614 & 162.250 & 80.364 & 238.136 & 160.925 & 77.211 \\
\hline$\%$ & 100 & 66,9 & 33,1 & 100 & 67,6 & 32,4 \\
\hline \multicolumn{7}{|l|}{ Polog } \\
\hline Number & 280.352 & 83.270 & 197.082 & 304.125 & 88.762 & 215.363 \\
\hline$\%$ & 100 & 29,7 & 70,3 & 100 & 56,6 & 43,4 \\
\hline \multicolumn{7}{|c|}{ Northeast } \\
\hline Number & 163.841 & 87.420 & 76.421 & 172.787 & 97.757 & 75.030 \\
\hline$\%$ & 100 & 53,4 & 46,6 & 100 & 56,6 & 43,4 \\
\hline \multicolumn{7}{|l|}{ Skopje } \\
\hline Number & 545.228 & & & 578.144 & 415.212 & 162.932 \\
\hline$\%$ & 100 & & & 100 & 71,8 & 28,2 \\
\hline
\end{tabular}

Source: State Statistical Office, Census of Population, Households and Dwellings in the Republic of Macedonia, 2002 (Book XII)

Regarding the representation of urban and rural populations we can separate two regions with significantly different characteristics. In the Pelagonian region the participation of urban population dominates in the total population $(66,9 \%$ in 1994 and $67,6 \%$ in 2002), and the participation of the rural population is significantly smaller and tends to reduce it to the rural population $(33,1 \%$ and $32,4 \%)$. 
Reverse situation was noticed in the Polog region, where the representation of the urban population was $29,5 \%$ (1994) and 29,2\% (2002), and the rural $70,5 \%$ and $70,8 \%$. According to the territorial organization of the 2004 Pelagonian region has four rural municipalities (Dolneni, Krivogastani, Mogila and Novaci), while in the Polog region all municipalities are rural, except Gostivar and Tetovo.

The analysis of the urban and the other population shows that in the period 1994-2002 the urban population grew in all regions except in the
Southwest and Polog, areas that are distinguished by a small share of the urban population. According to the existing territorial organization in 2002, almost half (41) of the municipalities in the country had only rural population. Quite a large number of rural communities substantially determines the regional demographic and socio-economic development in the country. Therefore, special attention should be paid to the continued depopulation of small rural communities, and thus the increase in low-populated areas in most regions.

Chart 2. Urban and rural population in the Republic of Macedonia, by regions 2002

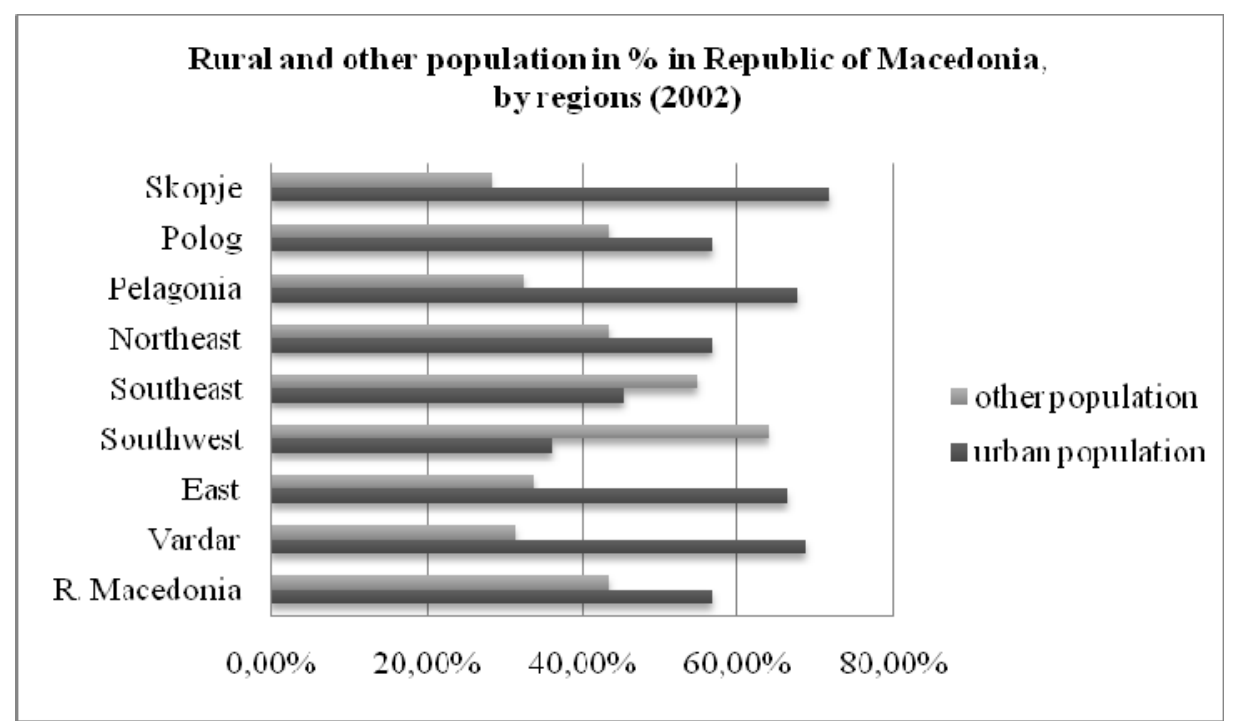

According to the population density we could differentiate six zones: areas with low concentrations of population density (50 inhabitants per $\mathrm{km}^{2}$ ), zones of medium concentration (51-100 inhabitants per $\mathrm{km}^{2}$ ), overpopulated zones (101-150 inhabitants per $\mathrm{km}^{2}$ ), significantly overpopulated zones (151-500 inhabitants per $\mathrm{km}^{2}$ ), very signifycantly overpopulated zones (501-1.000 inhabitants per $\mathrm{km}^{2}$ ) and extremely crowded areas (over 1000 inhabitants per $\mathrm{km}^{2}$ ) [14]. In 2002, in the Republic of Macedonia almost half (38) of the municipalities belong to an area with low population, 18 are characterized by a medium rate, 8 are overpopulated, 10 are largely overpopulated, 4 are major overpopulated, and in 6 municipalities the number of inhabitants per $\mathrm{km}^{2}$ is greater than 1.000 .

\section{REFERENCES}

[1] W. A. Baletić, Demografija (stanovništvo i ekonomski razvitak), Informator, Zagreb, 1973.
[2] V. Daskalovski, Demografski razvoj na naselenieto vo Republika Makedonija, Geografski razgledi, 30, Skopje, 1995.

[3] V. Daskalovski, Tendencii na demografskiot razvoj na Republika Makedonija, Zbornik od Vtoriot kongres na geografite na Republika Makedonia, Skopje, 2011.

[4] I. Nejašmić, Demogeografija, stanovništvo $u$ prostornim procesima i odnosima, Školska knjiga, Zagreb, 2005.

[5] M. J. A. Albala, Countering depopulation in rural Spain: The case of País Románico, master thesis, August, 2008.

[6] P. Eberhardt, Depopulation process in the Rural Areas in East-central Europe (1950-1990), Eastern European Countryside, 1990, pp. 31-40.

[7] M. Panov, Socijalna Geografija, Naselenie $i$ naselbi, Skopje, 1987.

[8] G. Grauser, Structural policies and depopulated areas in Europe, Depopulation seminar, 12-13 June, Lycksele: European Commission, 2001. 
[9] D. Breznik, Demografija, Analiza, metodi $i$ modeli, Naučna knjiga, Beograd, 1988.

[10] State Statistical Office, Natural Population Change, 2012.

[11] State Statistical Office, Republic of Macedonia, $S Y B, R M / 1962 ; S Y B, R M / 1972 ; S Y B, R M / 1982$.

[12] State Statistical Office, Republic of Macedonia, calculations, Demographic Statistics by regions and Census of population, households and dwellings in R. Macedonia, Book XIII, 2002.
[13] State Statistical Office, Demographic Statistics by regions and Census of population, households and dwellings in Republic of Macedonia, Book XII, 2002.

[14] United Nations Development Program (UNDP), Mapping of the socio-economic disparities among Macedonian municipalities, State Statistical Office, Ministry for Local Self-Government and UNDP, Skopje and New York, NY, 2004.

\section{ДЕМОГРАФСКИ АСПЕКТИ НА ТЕРИТОРИЈАЛНАТА РАЗМЕСТЕНОСТ И НИВОАТА НА УРБАНИЗАЦИЈА ВО РЕПУБЛИКА МАКЕДОНИЈА}

\section{Никола Панов, Милена Талеска, Христина Димеска}

Институт за географија, Природно-математички факултет, Универзитет „Св. Кирил и Методиј“, Скопје, Република Македонија

Република Македонија како и останатите европски земји го следи трендот на континуирано намалување на бројот на жители во поедини делови од државата. Паралелно со намалувањето на бројот на жители се јавува и опаѓање на стапката на пораст на населението, како и густината на населеност во поедини региони. На територијата на Република Македонија во однос на распределеноста на густината на населението забележани се видливи разлики во поедини делови, па и региони. Ваквите демографски промени биле предизвикани од влијанието на економските прилики во државата, како и од преселничките движења. Во трудот, покрај анализата на податоците за бројното движење на населението и густината на населеност (19532011), ќе бидат опсервирани основните обележја на урбаните и руралните средини од аспект на промените настанати во просторна разместеност на населението по региони, како и идентификација на факторите кои влијаеле кон создавање на разликите во денешната нерамномерна просторна дистрибуција на населението. средини

Клучни зборови: Република Македонија; број на жители; густина на населеност; урбани и рурални 